\title{
Compatibility of Polyvinyl Alcohol with the 241-F/H Tank Farm Liquid Waste
}

by

L. N. Oji

Westinghouse Savannah River Company

Savannah River Site

Aiken, South Carolina 29808

DOE Contract No. DE-AC09-96SR18500

This paper was prepared in connection with work done under the above contract number with the U. S. Department of Energy. By acceptance of this paper, the publisher and/or recipient acknowledges the U. S. Government's right to retain a nonexclusive, royalty-free license in and to any copyright covering this paper, along with the right to reproduce and to authorize others to reproduce all or part of the copyrighted paper. 


\section{DISCLAIMER}

This report was prepared as an account of work sponsored by an agency of the United States Government. Neither the United States Government nor any agency thereof, nor any of their employees, makes any warranty, express or implied, or assumes any legal liability or responsibility for the accuracy, completeness, or usefulness of any information, apparatus, product, or process disclosed, or represents that its use would not infringe privately owned rights. Reference herein to any specific commercial product, process, or service by trade name, trademark, manufacturer, or otherwise does not necessarily constitute or imply its endorsement, recommendation, or favoring by the United States Government or any agency thereof. The views and opinions of authors expressed herein do not necessarily state or reflect those of the United States Government or any agency thereof.

This report has been reproduced directly from the best available copy.

Available to DOE and DOE contractors from the Office of Scientific and Technical Information, P.O. Box 62, Oak Ridge, TN 37831; prices available from (615) 576-8401.

Available to the public from the National Technical Information Service, U.S. Department of Commerce; 5285 Port Royal Road, Springfield, VA 22161. 


\section{DISCLAIMER}

Portions of this document may be illegible in electronic image products. Images are produced from the best available original document. 
- WESTINGHOUSE SAVANNAH RIVER COMPANY

SAVANNAH RIVER TECHNOLOGY CENTER

COMPATIBILITY OF POLYVINYL ALCOHOL WTH THE 241-F/H TANK FARM LIQUID WASTE (U).

Author: Lawrence N. Oji \&.O

Report Date: October 28, 1998

Westinghouse Savannah River Company Savannah River Site

Aiken. SC 29808

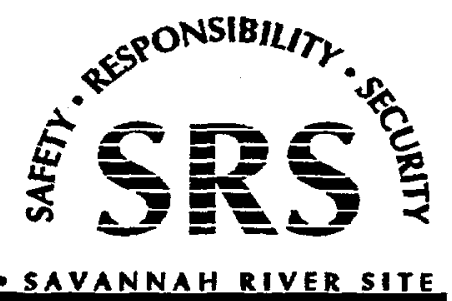


WESTINGHOUSE SAVANNAH RIVER COMPANY

SAVANNAH RIVER TECHNOLOGY CENTER.

COMPATIBILITY OF POLYVINYL ALCOHOL WTH THE 241-F/H TANK FARM LIQUID WASTE (U).
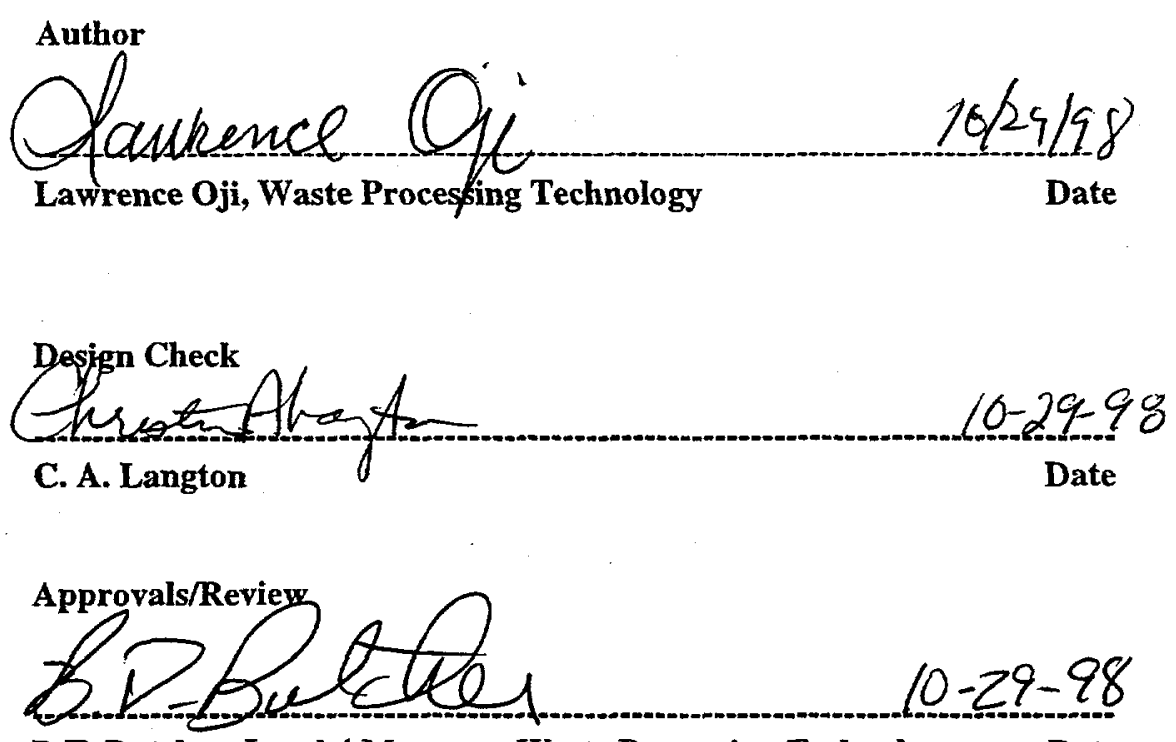

B.T. Butcher, Level 4 Manager, Waste Processing Technology Date

Westinghouse Savannah River Company

Savannah River Site

Aiken. SC 29808

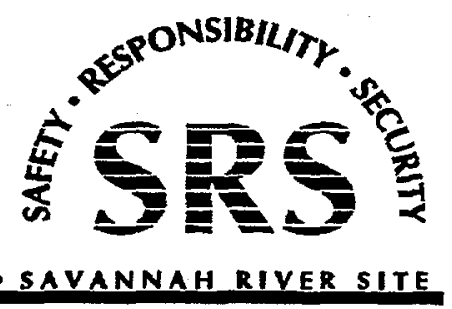




\section{COMPATIBILITY OF POLYVINYL ALCOHOL WTH THE 241-F/H TANK FARM LIQUID WASTE (U).}

\section{SUMMARY}

Keywords: Mineralization, Wipes, Peroxydisulfate, Orex ${ }^{\circledR}$ process, Vinyl alcohol Waste disposal, Decontamination.

This report describes results from laboratory-scale oxidative mineralization of polyvinyl alcohol (PVA), and the evaluation of the F/H Tank Farms as a storage/disposal option for PVA waste solution generated in the Canyons and B-line decontamination operations. Polyvinyl alcohol characterization data were evaluated against the Waste Acceptance Criteria (WAC) for High Level Liquid Waste Transfer to the 241-F/H Tank Farms and down stream waste processing facilities. Results are summarized below:

- A maximum of five-percent by weight of PVA solution can be prepared from the PVA fabric without serious dissolution problems. For practical purposes, a $4 \%$ by weight solution is recommended. PVA solution is expected to be pumpable in all proportions in water.

- "Neat" unadulterated PVA waste solutions will not meet Tank Farm corrosion and pH WAC requirements. These two concerns can, however, be remedied by carrying out a caustic adjustment with sodium hydroxide and blending of PVA waste solutions with other Tank Farm waste streams.

- If PVA is found in Tank Farm evaporator overheads, it may not be compatible with the Effluent Treatment Facility (ETF) WAC. PVA will be chemisorbed onto ETF carbon beds, thereby lowering the efficiency and operational life of these beds.

- "Neat" PVA solution will meet the composite low flammability limit ( $<25 \%$ CLFL) for the Tank Farm WAC.

- "Neat" PVA solution will not meet the stringent Tank Farm organic content WAC, which calls for less than 0.005 gallons of organic compound per gallon of aqueous waste. Therefore, a PVA oxidation process is required if an organic content deviation can not be obtained.

- Harsh oxidation conditions are required to mineralize and obtain higher percentage yield for PVA conversion to carbon dioxide and other simpler organic molecules. The Orex ${ }^{\circledR}$ process may need extensive modification to accommodate oxidation conditions.

- The maximum percentage yield $(>19 \%$ conversion of PVA to smaller molecules and carbon dioxide) in the oxidative mineralization of PVA was obtained with acidified potassium permanganate and palladium catalyzed reactions.

- The resulting solution $\mathrm{pH}$ for palladium and hydrogen peroxide catalyzed oxidation of PVA is greater than 9.5, and thus will meet Tank Farm pH WAC requirement

- PVA and its possible degradation products (acetates and formates) meet the composite low flammability limit ( $<25 \%$ CLFL) for the Tank Farm WAC. 
More tests, including the following will need to be conducted with PVA solutions to evaluate its compatibility with the Tank Farm chemistry and down stream waste processing facilities:

- Determine changes in the viscosity of PVA solution with evaporation of water.

- Determine whether PVA in solution can influence the solubility product of radionuclides and their salts, thereby causing selective precipitation or dissolution of these radionuclides with changes in $\mathrm{pH}$, thermal and other conditions.

- The partitioning of PVA into the vapor phase (evaporator overhead), salt solution and sludge bottoms will need to be determined. This information will be useful in determining how the disposal of PVA through the Tank Farms will affect down stream operations like the ETF and In-tank precipitation (ITP) processes.

- Radiolytic degradation of PVA and the generation of flammable gases like hydrogen need to be evaluated.

- Identify the principal oxidation products from the mineralization of PVA.

\subsection{INTRODUCTION}

Cellulose-based mop heads, wipes and disposable personal protection clothing are currently used as "clean up" products at the Savannah River Site (SRS). These conventional cleaning materials are used in the Canyons and B-line operations for picking up radioactive spills and mixed waste as well as in general decontamination operations. Cellulose and other polymer-based materials, which can not be laundered or incinerated due to high radioactive contamination, organic constituents or mixed waste characteristics are disposed in dry active waste streams (LLW and TRU waste streams) as bulky solid waste. Increasing cost of final disposal of these types of solid waste makes it necessary to investigate new ways of decreasing low-level radioactive waste volume.

PVA material is a white woven fabric, which according to the vendors and manufacturer ${ }^{\#}$ does not contain inorganic or organic coloring agents. The principal advantage of PVA based "clean up" is that it is soluble in highly polar and hydrophilic solvents, such as water, dimethyl sulfoxide, acetamide, glycols and dimethyl formamide (DMF): It can be readily converted into a solution of polyvinyl alcohol when it is treated with hot water at 90-100 ${ }^{\circ} \mathrm{C}$. The PVA material and resulting solution is also biodegradable. PVA is virtually unaffected by organic solvents like hydrocarbons, chlorinated hydrocarbons, carboxylic acid esters, greases and vegetable oils. Table 1 below shows a summary of relevant physical properties of PVA (1). PVA is a non-hazardous material according to the American Standard for Precautionary Labeling of Hazardous Industrial Chemicals (ANSI 2129. 1-1976).

The first goal of this investigation is to characterize and evaluate "neat" or unadulterated waste PVA solution (eventually bearing $<100 \mathrm{nCi} / \mathrm{g}$ of TRU waste) and determine if it can be disposed of through the High Level Waste 241-F/H Tank Farms. If "neat" PVA solutions can not meet the Tank Farm WAC due to factors such as high organic content,

\# Air Products Chemical Inc. Phone: 610-481-4911 
the second goal would then involve evaluating chemical oxidative mineralization techniques which will be compatible with industrial processes for converting PVA fabric into solution (Orex ${ }^{\circledR}$ process $^{*}(1)$ ).

The maximum level of TRU waste expected in these used PVA solutions is lower than $100 \mathrm{\eta Ci} / \mathrm{g}$, and in order to evaluate the impact of PVA solution on High Level Waste Tank Farm chemistry the following questions will need to be addressed:

- Determining whether water based solution of PVA fabric material, without any further chemical treatment or modifications (mineralization to carbon dioxide and water) will meet the 241-F/H Tank Farms Waste Acceptance Criteria (WAC) for storage and disposal. The "neat' PVA solution must also be compatible with the Tank Farm down stream waste processing facilities such as the Effluent Treatment Facility (ETF and saltstone).

- Determining an effective way of chemically decomposing PVA solution such that a commercial technology (Orex ${ }^{\circledast}$ process) can be easily modified to achieve PVA mineralization to simpler organic compounds, carbon dioxide and water.

The PVA decomposition process to reduce the organic.content of the PVA solution is expected to produce a solution, which would also meet the 241-F/H Tank Farms and down stream waste processing facility WAC.

\section{$2.0 \quad$ APPROACH}

Five- percent "neat" PVA solution prepared by dissolving PVA fabrics in hot water at $90-100{ }^{\circ} \mathrm{C}$ and mineralized PVA solutions will be characterized and evaluated against F/H Tank Farm WAC. A decrease in total organic carbon (TOC) will be used as the only means of measuring extent of the oxidation. If a 5\% "neat" PVA solution meets all the F/H Tank Farm WAC, assuming that there are no other operational concerns such as the availability of tank space, then PVA solutions will be recommended for disposal at the Tank Farms without further treatment. On the other hand, if the PVA solution does not meet the F/H Tank Farm WAC, the organic concentration requirement or others, then an attempt will be made to carry out nonselective oxidative mineralization of PVA solution to simpler organic compounds to reduce its total organic carbon content.

\subsection{EXPERIMENTAL}

All chemicals used in this study were reagent grade and required no special treatment. Distilled water was used in the preparation of 5\% PVA stock solutions (by weight). For example, the 5\% PVA solution was prepared by dissolving 100 grams of PVA fabric in a 4-Liter beaker sitting on a hot plate equipped with a magnetic stirrer and containing approximately 2-Liters of boiling water. The $2.5 \%$ PVA stock solution was obtained by

\footnotetext{
" Modified commercial washing unit designed to dissolve PVA fabric waste in hot water at $\approx 100$ ' $\mathrm{C}$.
} 
serial dilution of the 5\% PVA stock solution. The maximum PVA solution that could be prepared under the above conditions (dissolution of PVA fabric in hot water) without serious dissolution problems was $5 \%$.

This laboratory-scale mineralization of PVA with oxidation reagents was carried out in a half-liter flask fitted with a reflux condenser and an external-heating mantle connected to a variable transformer (Variac). One arm of the reaction vessel bore a thermometer, which was inserted about $0.5 \mathrm{~cm}$ from the liquid phase. The off-gas from the reaction flask was passed into a beaker with distilled water. To charge the reaction vessel, for example, $90 \mathrm{ml}$ of the stock solution (5 or $2.5 \%$ PVA solution) was introduced into it along with $5 \mathrm{ml}$ of the potassium permanganate solution $(0.25 \mathrm{M})$. Five milliliters of either sulfuric acid $(0.25, \mathrm{M})$, nitric acid $(0.25 \mathrm{M}$ each) or $5 \mathrm{ml}$ of $3 \%$ solution of hydrogen peroxide was further added into the reaction mixture to increase the oxidation potential of the potassium permanganate. This brought the apparent total solution volume to $100 \mathrm{ml}$. In cases when 1.0 gram of palladium powder catalyst was used (average particle size of 6 microns) in place of hydrogen peroxide, nitric acid or sulfuric acid, $4 \mathrm{ml}$ of distilled water was added as the make up volume. After charging the reaction vessel the temperature of the reaction mixture was slowly raised to $90-100{ }^{\circ} \mathrm{C}$ by adjusting the variac or temperature controller. Heating was carried out for one hour after the desired temperature, $100^{\circ} \mathrm{C}$, had been attained.

Samples collected for analysis included initial reference sample $(90 \mathrm{ml}$ of stock solution plus $10 \mathrm{ml}$ of distilled water), pre- and post heated samples. The last category of samples in some cases included samples taken at various stages of heating $(1.0,1.5,2.0,2.5$ and 3.0 hours). The principal measurements analyzed for were total organic carbon (TOC), free hydroxyl ions $\left(\mathrm{OH}^{-}\right)$concentration and $\mathrm{pH}$. See data summary in Table 2.

PVA oxidation with $\mathrm{KMnO}_{4}$, Acidified $\mathrm{KMnO}_{4}$ and Peroxydisulfates

In the initial screening runs, four different oxidizing agents $\left(\mathrm{KMnO}_{4}\right.$, acidified $\mathrm{KMnO}_{4}$ $\left(\mathrm{H}_{2} \mathrm{SO}_{4}\right)$, ammonium and sodium peroxydisulfates) were evaluated. Of the four agents used in the oxidation reaction to determine the extent of PVA conversion into simpler molecules, only sodium and ammonium peroxydisulfate containing samples failed to show any signs of PVA decomposition or mineralization. There were no gases evolved, as expected. With these peroxydisulfates the PVA solutions instead re-polymerized into a solid yellow gel. The sulfites, as would be expected of most peroxide reaction with a polymer solution, instead promoted the polymerization of PVA to a yellow jelly-like cake. The TOC for potassium permanganate treated PVA did not change significantly when compared to TOC for the PVA. Only the sulfuric acid treated permanganate plus PVA solution (5 and $2.5 \%$ solution) showed any changes in TOC after heating for one hour. For the $5 \%$ PVA solution the TOC dropped from about 25,790 down to 25,490 , which is about a $1 \%$ decrease in TOC. The $2.5 \%$ PVA solution showed a slightly more decrease in TOC; from about 12,110 to 11770 , which is about 2.8 percent decrease in TOC.

The $\mathrm{pH}$ of the resulting heated and room temperature cooled solution was 7.30 for the $5 \%$ PVA solution and 6.20 for the $2.5 \%$ PVA solution. The free hydroxyl ion concentrations 
for both solutions were less than $0.002 \mathrm{mg} / \mathrm{L}$ (Table 2). Note only single runs were carried out in the screening runs to cut down on analytical cost.

PVA oxidation with Acidified $\mathrm{KMnO}_{4}, \mathrm{H}_{2} \mathrm{O}_{2}$ and $\mathrm{Pd}$

The reduction of potassium permanganate, as reflected in the disappearance of the purple potassium permanganate color, occurred in all reactions containing nitric and sulfuric acids, hydrogen peroxide and palladium catalyst. The addition of Palladium catalyst or hydrogen peroxide to the reaction mixture (2.5\% PVA and potassium permanganate) resulted in the evolution of more gases at lower temperatures $\left(<50^{\circ} \mathrm{C}\right)$ in comparison to reaction mixtures containing only acidified potassium permanganate. In cases when palladium catalyst was used, the reaction mixture initially turned into a gel-like paste. This paste slowly turned into a viscous liquid mixture and then into a free flowing mixture after shaking it at room temperature for about ten minutes and slowly raising the temperature. For reactions with $\mathrm{Pd}$ catalyst/KMnO 4 and $2.5 \%$ PVA the drop in TOC was approximately $21 \%$. With hydrogen peroxide, the drop in TOC was about $11 \%$. When the above oxidations were carried out with $5 \%$ PVA solutions the drops in TOC for Pd $/ \mathrm{KMnO}_{4}$ catalyzed reaction was $12.5 \%$ and $11 \%$ for $\mathrm{H}_{2} \mathrm{O}_{2} / \mathrm{KMnO}_{4}$. In both cases the pH of the cooled solutions was more than 10 .

Using palladium and hydrogen peroxide based reaction mixtures, samples were taken at various heating times (1.0, 1.5, 2.0, 2.5 and 3.0 hours) and sent for TOC and $\mathrm{pH}$ analysis. Both groups of samples showed a steady decrease in TOC with increase in heating time. The $\mathrm{pH}$ values of the end product mixtures or solutions were all above 10 .

For fear of precipitating explosive $\mathrm{Mn}_{2} \mathrm{O}_{7}$, the use of sulfuric acid was discontinued and replaced with nitric acid, which reduced any solid manganese dioxide produced during the reaction. Heated and acidified (nitric acid) permanganate solutions plus 5\% PVA solution showed about a $19 \%$ decrease in TOC. This nitric acidified permanganate was a more effective oxidation mixture than sulfuric acid based mixtures with permanganate.

In all the runs, the refluxing conditions were maintained to minimize concentrating of the reaction mixture due to loss of water vapor.

\begin{tabular}{|l|l|l|}
\hline Property & Value & Remarks \\
\hline Appearance & White to ivory white & PVA material fabric \\
\hline Vapor pressure & $<1 \mathrm{mmHg}$ & In all percent proportions in water. \\
\hline Lower flammability limit & $\begin{array}{l}\text { Little or no vapor phase at } \\
5 \% \text { composition in water }\end{array}$ & $\begin{array}{l}\text { Information from PVA manufacturer } \\
\text { (Air Products Chemical Inc.: } \\
610-481-4911)\end{array}$ \\
\hline Density of 5\% solution & $1.05 \pm 0.02 \mathrm{~g} / \mathrm{cc}$ & At $26^{\circ} \mathrm{C}$, (Laboratory determination) \\
\hline Density of $2.5 \%$ solution & $0.99 \pm 0.02 \mathrm{~g} / \mathrm{cc}$ & At $26^{\circ} \mathrm{C}$ (Laboratory determination) \\
\hline Density of 100\% PVA & $1.27-1.31 \mathrm{~g} / \mathrm{cc}$ & Increases with degtee of crystallinity \\
\hline Melting point & $200^{\circ} \mathrm{C}$ & PV A material fabric \\
\hline Thermal stability & $\begin{array}{l}\text { Gradual discoloration above } \\
100{ }^{\circ} \mathrm{C} \text {. Darkens above } 150 \\
{ }^{\circ} \mathrm{C} \text { and rapid decomposition } \\
\text { above } 200^{\circ} \mathrm{C}\end{array}$ & PVA material fabric \\
\hline
\end{tabular}

Table 1 . Summary of relevant physical properties for polyvinyl alcohol. 


\begin{tabular}{|c|c|c|c|c|}
\hline Lims\# & Sample ID & TOC $(\mathrm{mg} / \mathrm{L})$ & {$[\mathrm{OH}-](\mathrm{mg} / \mathrm{L}) /$} & Comments \\
\hline & & & $\mathbf{p H}$ & \\
\hline $3-112401$ & B5PVAPS & 25,790 & $<0.002$ & $5 \% \mathrm{PVA}+\mathrm{KmnO}_{4}+\mathrm{H}_{2} \mathrm{SO}_{4} @ \mathrm{RT}$ \\
\hline $3-112402$ & H5PVAPS & 25,490 & $\begin{array}{l}<\quad 0.002 \\
(\mathrm{pH}=7.30)\end{array}$ & $5 \% \mathrm{PVA}+\mathrm{KmnO}_{4}+\mathrm{H}_{2} \mathrm{SO}_{4}$ Heated \\
\hline $3-112403$ & B2.5PVAPS & 12,110 & NA & $2.5 \% \mathrm{PVA}+\mathrm{KmnO}_{4}+\mathrm{H}_{2} \mathrm{SO}_{4} @ \mathrm{RT}$ \\
\hline $3-112404$ & H2.5PVAPS & 11,770 & $\mathrm{NA}(\mathrm{pH}=6.20)$ & $2.5 \% \mathrm{PVA}+\mathrm{KmnO}_{4}+\mathrm{H}_{2} \mathrm{SO}_{4}$ Heated \\
\hline 3-112405 & 2.5PVA & $12,350 \pm 120$ & $<\underset{(\mathrm{pH}=7.40)}{0.002}$ & TOC for $2.5 \%$ PVA solution \\
\hline $3-112406$ & H2.5PVAP & 12,260 & $\mathrm{NA}(\mathrm{pH}=9.80)$ & $2.5 \%$ PVA $+\mathrm{KMnO}_{4}$ only (Heated) \\
\hline $3-112407$ & H2.5PVAPH & 10,950 & $\mathrm{NA}(\mathrm{pH}=7.97)$ & $2.5 \% \mathrm{PVA}+\mathrm{KMnO}_{4}+\mathrm{H}_{2} \mathrm{O}_{2}$ (Heated) \\
\hline $3-112408$ & 2.5PVAPPd & 9,646 & $\mathrm{NA}(\mathrm{pH}=8.91)$ & $2.5 \% \mathrm{PVA}+\mathrm{KmnO}_{4}+$ Pd cat. (Heated) \\
\hline 3-112409 & 5PVA & $25,610 \pm 180$ & $<0.002$ & TOC for 5\% PVA solution \\
\hline $3-113194$ & PHNORT & 25,920 & NA & $5 \% \mathrm{PVA}+\mathrm{KMnO}_{4}+\mathrm{HNO}_{3} @ \mathrm{RT}$ \\
\hline $3-113195$ & PHNOHT & 21,050 & $(\mathrm{pH}=2.45)$ & $5 \% \mathrm{PVA}+\mathrm{KMnO}_{4}+\mathrm{HNO}_{3}$ (Heated) \\
\hline $3-113196$ & PdRT & 25,240 & $\mathrm{NA}(\mathrm{pH}=11.20)$ & $5 \% \mathrm{PVA}+\mathrm{KMnO}_{4}+$ Pd Catalyst @ RT \\
\hline $3-113197$ & PdHT & 22,110 & $(\mathrm{pH}=11.43)$ & $5 \% \mathrm{PVA}+\mathrm{KMnO}_{4}+$ Pd Catalyst (Heated) \\
\hline $3-113198$ & PH2O2RT & 25,600 & $\widehat{\mathrm{NA}}$ & $5 \% \mathrm{PVA}+\mathrm{KMnO}_{4}+\mathrm{H}_{2} \mathrm{O}_{2} @ \mathrm{RT}$ \\
\hline $3-113199$ & PH2O2HT1.0 & 22,870 & & $5 \% \mathrm{PVA}+\mathrm{KMnO}_{4}+\mathrm{H}_{2} \mathrm{O}_{2}$ (Heated-1Hr.) \\
\hline $3-113200$ & PH2O2HT1.5 & 22,130 & $\mathrm{NA}(\mathrm{pH}=10.11)$ & $5 \% \mathrm{PVA}+\mathrm{KMnO}_{4}+\mathrm{H}_{2} \mathrm{O}_{2}$ (Heated-1.5 Hrs.) \\
\hline 3-113201 & PH2O2HT2.0 & 21,590 & NA & $5 \% \mathrm{PVA}+\mathrm{KMnO}_{4}+\mathrm{H}_{2} \mathrm{O} 2$ (Heated-2 Hrs.) \\
\hline $367-2257$ & Ppd1.0 & 22,680 & $\mathrm{NA}(\mathrm{pH}=11.20)$ & $5 \% \mathrm{PVA}+\mathrm{KMnO}_{4}+\mathrm{Pd}$ Cat. heated for $1 \mathrm{hr}$ \\
\hline $367-2258$ & Ppd1.5 & 22,460 & NA & $5 \% \mathrm{PVA}+\mathrm{KMnO}_{4}+\mathrm{Pd}$ Cat. heated for $1.5 \mathrm{hr}$ \\
\hline $367-2259$ & Ppd2.0 & 22,380 & NA & $5 \% \mathrm{PVA}+\mathrm{KMnO}_{4}+\mathrm{Pd}$ Cat heated for $2.0 \mathrm{hr}$ \\
\hline $367-2260$ & Ppd2.5 & 22,180 & $\mathrm{NA}(\mathrm{pH}=$ & $5 \% \mathrm{PVA}+\mathrm{KMnO}_{4}+\mathrm{Pd}$ Cat. heated for $2.5 \mathrm{hr}$ \\
\hline $367-2261$ & Ppd3.0 & 21,290 & NA & $5 \% \mathrm{PVA}+\mathrm{KMnO}_{4}+\mathrm{Pd}$ Cat. heated for $3.0 \mathrm{hr}$ \\
\hline
\end{tabular}

Table 2. Summary PVA oxidation results with potassium permanganate in $\mathrm{HNO}_{3}, \mathrm{H}_{2} \mathrm{O}_{2}$, $\mathrm{Pd}$ Catalyst and $\mathrm{H}_{2} \mathrm{SO}_{4}$. There is a definite decrease in total organic compound with oxidation of PVA in acidified permanganate and in the presence of $\mathrm{Pd}$ catalyst.

\begin{tabular}{|l|l|l|l|}
\hline Reagents & Percent PVA & $\begin{array}{l}\text { Percent decrease in } \\
\text { TOC }\end{array}$ & Comments \\
\hline $\mathrm{KMnO}_{4}$ & 2.5 & $<1 \%$ & \\
\hline $\mathrm{KMnO}_{4} / \mathrm{H}_{2} \mathrm{SO}_{4}$ & 2.5 & $<3 \%$ & Precipitates manganese oxides \\
\hline $\mathrm{KMnO}_{4} / \mathrm{H}_{2} \mathrm{SO}_{4}$ & 5.0 & $<1 \%$ & Precipitates manganese oxides \\
\hline $\mathrm{KMnO}_{4} / \mathrm{Pd}$ & 2.5 & $21 \%$ & \\
\hline $\mathrm{KMnO}_{4} / \mathrm{Pd}$ & 5.0 & $12 \%$ & \\
\hline $\mathrm{KMnO}_{4} / \mathrm{H}_{2} \mathrm{O}_{2}$ & 2.5 & $11 \%$ & \\
\hline $\mathrm{KMnO}_{4} / \mathrm{H}_{2} \mathrm{O}_{2}$ & 5.0 & $12 \%$ & \\
\hline $\mathrm{KMnO}_{4} / \mathrm{H}_{2} \mathrm{NO}_{3}$ & 5.0 & $19 \%$ & \\
\hline
\end{tabular}

Table 3. Summary of oxidation results for PVA mineralization. Nitric acid acidified Potassium Permanganate or combined with Pd catalyst gave the best results. 


\subsection{DISCUSSION}

The dissolution of PVA fabric material in hot water at $90-100{ }^{\circ} \mathrm{C}$ is actually a phase change involving the conversion of the material into a liquid solution of PVA. Table 2 contains a summary of the data obtained in the various runs with oxidizing agents to mineralize PVA to acetic, carbon dioxide and other simpler organic molecules [Note, no attempt was made to identify or characterize the mineralization products for PVA in this study]. The average total organic carbon (TOC) obtained for a 5\% PVA solution is $25,610 \pm 180 \mathrm{ppm}(\mathrm{mg} / \mathrm{L})$. In the oxidation runs potassium permanganate was used as the principal oxidizing agent. Sulfuric acid, nitric acid and hydrogen peroxide were added to increase the oxidation potential of the permanganate. For example, the oxidation potential of acidified potassium permanganate is 1.68 volts and that of neutral potassium permanganate is 0.58 volts (3). Combinations of permanganate with each of the above auxiliary oxidizing agents were used to initiate breakdown of PVA solution. Palladium catalyst was also combined with potassium permanganate to obtain a measure of the extent of PVA mineralization in the presence of a transition metal catalyst.

The first few runs with oxidizing agents $\left(\mathrm{KMnO}_{4}, \mathrm{HNO}_{3}, \mathrm{H}_{2} \mathrm{O}_{2}, \mathrm{Pd}\right.$ Catalyst and $\mathrm{H}_{2} \mathrm{SO}_{4}$ ) were carried out as screening runs to identify the best oxidizing agents for PVA. The oxidation of 5\% PVA solution with sulfuric acid acidified potassium permanganate solution produced a solution with a slight decrease in TOC (1\% less carbon). The decrease in TOC using 2.5\% PVA solution in $\mathrm{KMnO}_{4} / \mathrm{H}_{2} \mathrm{SO}_{4}$ was also not significant (just under 3\%). With $\mathrm{KMnO}_{4}$ and $2.5 \%$ PVA solution only, the decrease in TOC was less than $1 \%$ and was about $11 \%$ in a $\mathrm{KMnO}_{4} / \mathrm{H}_{2} \mathrm{O}_{2}$ reaction mixture. The decrease in TOC for a $\mathrm{KMnO}_{4} / \mathrm{Pd}$ catalyst in a $2.5 \%$ PVA solution was about $21 \%$. On the other hand, the decrease in $\mathrm{TOC}$ for a $\mathrm{KMnO}_{4} / \mathrm{Pd}$ catalyst with $5 \%$ PVA solution was just above $12 \%$.

As expected, runs with lower percent PVA gave better oxidation results (lower final TOC than beginning TOC numbers) in the presence and equal concentration of the same oxidizing agent. Above all, $\mathrm{KMnO}_{4} / \mathrm{HNO}_{3}$ with 5\% PVA solution showed a higher decrease (almost $19 \%$ ) in TOC than the $\mathrm{KMnO}_{4} / \mathrm{Pd}$ catalyst with a 5\% PVA.

Therefore, based on these TOC numbers only the palladium catalyst, $3 \%$ hydrogen peroxide and nitric acid additives to the oxidizing agent, potassium permanganate $\left(\mathrm{KMnO}_{4}\right)$, produced any appreciable decrease in TOC of PVA solutions (see Table 3 summary). Potassium permanganate/sulfuric acid $\left(\mathrm{KMnO}_{4} / \mathrm{H}_{2} \mathrm{SO}_{4}\right)$ oxidizing agent mixture was not as effective as the other oxidizing combinations in the mineralization of PVA. In addition, the acidification of potassium permanganate with sulfuric acid may precipitate explosive manganese peroxide $\left(\mathrm{Mn}_{2} \mathrm{O}_{7}\right)$.

The maximum percent by volume of PVA that can be produced by dissolving PVA fabric in hot water without any dissolution problems was observed in the laboratory to be $5 \%$. This concentration or even $2.5 \%$ PVA solution in water will not meet the stringent Tank Farm WAC for organic concentration in waste stream. This part of the WAC calls for less than 0.005 gallons of organic compound per gallon of aqueous waste (Maximum PVA in 
waste water received in Tank Farm shall be $<0.5$ vol. \% O/A). Therefore, in order to process PVA solutions through the Tank Farm a way must be sought to reduce the total Organic carbon content of PVA solution waste.

The oxidative mineralization attempt described above to convert PVA to carbon dioxide and acetic acid can only be achieved under very harsh oxidation conditions. These conditions would include temperatures greater than $100^{\circ} \mathrm{C}$ and possibly as high as $250^{\circ} \mathrm{C}$ in the presence of possibly acidified potassium permanganate or transition metal catalysts (in a totally closed system to minimize radionuclide contamination and assuming criticality is not a concern). The only problem is that the Orex ${ }^{\circledR}$ commercial process was not designed to meet these extreme conditions. Therefore to attain up to $75 \%$ mineralization of PVA to smaller molecules, the process may need to be modified to meet the above conditions for PVA mineralization. Preferably, the Orex ${ }^{\circledR}$ process will need to be redesigned to operate at temperatures between 200 and $250{ }^{\circ} \mathrm{C}$ and under a moderately pressurized state.

PVA and its possible degradation products meet (acetates and formates) the composite low flammability limit (CLFL) for the Tank Farm. The lower flammability limit for $100 \%$ PVA solution is less than $1 \%$ as compared to that for $100 \%$ acetic acid, $4 \%$ (4) and less than $6 \%$ for $100 \%$ formic acid. Since the PVA waste solution generated from the Bline and Canyon operations will be less than $10 \%$ PVA, the CLFL will not even approach the Tank Farm CLFL WAC requirement of less than $25 \%$. Therefore, PVA vapor phase in equilibrium with liquid phase PVA/water will not be flammable.

PVA solution contains less than 0.002 moles per liter of free hydroxyl radical $\left(\mathrm{OH}^{-}\right)$and is low in nitrite corrosion inhibitors. Tank Farm WAC calls for a minimum corrosion inhibitor content greater than 1.0 mole of free hydroxyl radical if the nitrite content of the waste stream is less than 0.02 mole. The average $\mathrm{pH}$ of a $5 \%$ PVA solution is about 7.05 , whereas Tank Farm WAC requires a waste stream with $\mathrm{pH}$ greater than 9.5 . It therefore will not meet Tank Farm corrosion and $\mathrm{pH}$ WAC requirements. It is worth noting that the $\mathrm{pH}$ of potassium permanganate/palladium or hydrogen peroxide PVA oxidized solutions averages about 11 . These two concerns, however, can be remedied by carrying out a caustic adjustment with sodium hydroxide and blending of PVA waste solutions with other Tank Farm waste streams.

Both "neat" and mineralized PVA solutions are considered pumpable and will meet the Tank Farm temperature requirement of $70{ }^{\circ} \mathrm{C}$ since it will be received in an organic designated pump tank.

\subsection{RECOMMENDATIONS}

A maximum of five-percent by weight of PVA solution can be prepared from the PVA fabric without serious dissolution problems. For practical purposes, a $4 \%$ by weight solution is recommended. PVA solution is expected to be pumpable in all proportions in water. A "Neat" unadulterated PVA waste solution will not meet Tank Farm corrosion 
and $\mathrm{pH}$ WAC requirements. However, it will meet the composite low flammability limit $(<25 \%$ CLFL) for the Tank Farm WAC.

If PVA is found in Tank Farm evaporator overheads, it may not be compatible with the Effluent Treatment Facility WAC. PVA, being an oxygenated organic compound, will be chemisorbed onto ETF carbon beds, thereby lowering the efficiency and operational life of these beds. A Neat" PVA solution will not meet the stringent Tank Farm organic content WAC, which calls for less than 0.005 gallons of organic compound per gallon of aqueous waste. Therefore, a PVA oxidation process is required if an organic content deviation can not be obtained.

Harsh oxidation conditions are required to mineralize and obtain higher percentage yield for PVA conversion to carbon dioxide and other simpler organic molecules. Therefore, the Orex ${ }^{\circledR}$ process may need extensive modification to accommodate oxidation conditions. In this laboratory-scale oxidation study, the maximum percentage yield ( $>19 \%$ conversion of PVA to smaller molecules and carbon dioxide) in the oxidative mineralization of PVA was obtained with acidified potassium permanganate and palladium catalyzed reactions. The resulting solution $\mathrm{pH}$ for palladium and hydrogen peroxide catalyzed oxidation of PVA is greater than 9.5, and thus will meet Tank Farm $\mathrm{pH}$ WAC requirement. PVA and its possible degradation products (acetates and formates) meet the composite lower flammability limit ( $<25 \%$ CLFL) for the Tank Farm WAC.

Since both ammonium and sodium peroxidisulfates did initiate polymerization and the formation of gel in PVA solution, most inorganic and organic peroxides can not be used as oxidizing agents for PVA.

More tests, including the following will need to be conducted with PVA solutions to evaluate its compatibility with the Tank Farm chemistry and down stream waste processing facilities:

- Determine changes in the viscosity of PVA solution with evaporation of water.

- Determine whether PVA in solution can influence the solubility product of radionuclides and their salts, thereby causing selective precipitation or dissolution of these radionulicdes with changes in $\mathrm{pH}$, thermal and other conditions.

- The partitioning of PVA into the vapor phase (evaporator overhead), salt solution and sludge bottoms will need to be determined. This information will be useful in determining how the disposal of PVA through the Tank Farms will affect down stream operations like the ETF and In-tank precipitation (ITP) processes.

- Radiolytic degradation of PVA and the generation of flammable gases like hydrogen need to be evaluated.

- Identify the principal oxidation products from the mineralization of PVA. 


\subsection{REFERENCES}

(1) Ocasio. M.W. "Polyvinyl alcohol appications in radioactive Waste Management" Journal of Applied Health Physics, July/August 1997, Vol.14, No. 4, pages 22-27.

(2) Concise Encyclopedia of Polymer Science and Engineering . John Wiley and Sons Publication, (1990).

(3) Weast, R. C. "Handbook of Chemistry and Physics" (1976). 56th Edition, CRC Press, Inc., Boca Raton, Florida.

(4) National. Fire Codes, published by the National Fire Protection Association, NFPA section 325. 